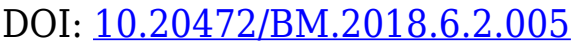

\title{
MANAGEMENT ACCOUNTANTS' ROLE IN MOVING TOWARDS A CORPORATE SUSTAINABILITY IN THAILAND
}

\author{
PHANTHIPA SRINAMMUANG, NEUNGRUTHAI PETCHARAT
}

\begin{abstract}
:
This study examines (1) management accountants' roles in driving sustainable success to create a corporate sustainability, (2) environmental information in annual reports based on the indicators of the Global Reporting Initiatives (GRI), and (3) environmental information in the reports and the information identified by the environmental management accounting (EMA) practices. Management accountants drive as a collaborator with a company to provide environmental information incorporating in the reports for investment decisions. A set of survey is created to conduct environmental performance indicators in annual reports of 2011 and 2012 of two-hundred listed companies in Thailand. Regression analysis is considered appropriate for this study to analyse the relationship among variables. The results reveal that environmental information incorporated in annual reports is positively relevant to the indicators of the GRI guidelines. Environmental information in the reports is also significantly related to the data identified based on the EMA practices. Although management accountants are not fully involved in capturing data, they are intending to play an important role in creating sustainable value towards a corporate sustainability. Thus, management accountant's roles in driving as a collaborator with a company are related to creating a corporate sustainability from promoting environmental sustainability significantly.
\end{abstract}

\section{Keywords:}

roles of management accountants, environmental sustainability accounting, environmental management accounting, environmental indicators, GRI

JEL Classification: M41

\section{Authors:}

PHANTHIPA SRINAMMUANG, Faculty of Business Administration, KASETSART UNIVERSITY, Thailand, Email: phanthipas@yahoo.com

NEUNGRUTHAI PETCHARAT, Gulf College of Oman, Oman, Email: neungruthai@gulfcollege.edu.om

\section{Citation:}

PHANTHIPA SRINAMMUANG, NEUNGRUTHAI PETCHARAT (2018). Management accountants' role in moving towards a corporate sustainability in Thailand. International Journal of Business and Management, Vol. VI(2), pp. 78-89., 10.20472/BM.2018.6.2.005 


\section{Introduction}

The emergence of environmental performance and variations in its implementation has become increasingly important to create a corporate sustainability both immediately and in future (Watchaneeporn Setthasakko, 2010). Environmental data in a company's reports is now more important than ever to put into practice the concept of sustainable development, which integrates economic growth, social development, and protection of the environment (Muttanachai Suttipun \& Patricia Stanton, 2012; UN, 2008). Environmental management accounting (EMA) practices have been therefore used as a business strategy to develop environmental management and economic performance in order to reach sustainability goals (Bennett \& James, 1998). Meanwhile, stakeholders have been more concerned about how environmental sustainability in a company's reports meet internationally environmental standards (Somporn Thapanachai, 2000; Tungrhapheephakorn, 2001cited in Kuasirikun and Sherer (2004)). In relation to this, international measure such as ISO 14000 for Environmental Management and ISO 18000 for Health and Safety at Work Management can help ensure that business practices meet environmental development requirements (Nongnooch Kuasirikun \& Sherer, 2004). This includes the environmental indicators based on the Global Reporting Initiatives that provides helpful guidance on environmental requirements (Neungruthai Petcharat \& Mula, 2013; Nickie Petcharat \& Mula, 2012). In Thailand, however, little is known about environmental management accounting practices. Environmental information incorporated in a company's reports provided as online information most likely focuses on the positive images and reputation thus supporting interests of stakeholders and public (Rowbottom \& Lymer, 2009; Thapat Silalertruksa \& Gheewala, 2012). Companies report their environmental performance against the backdrop of environmental issues affecting local community where they operate (Pareena Prayukvong \& Olsen, 2014). As a result, environmental information in a company's reports is mainly disclosed as little as possible in the informative form. This information does not clearly illustrate how a company achieves its environmental sustainability (Nongnooch Kuasirikun \& Sherer, 2004; Panisara Kongpunya, Phapruke Ussahawanitchakit, \& Chularat Khankaew, 2011; Pareena Prayukvong \& Olsen, 2014; Watchaneeporn Setthasakko, 2010). This study therefore examined the relationship between (1) environmental data in a company's reports and the indicators of the Global Reporting Initiatives (GRI), (2) environmental indicators in a company's reports and the environmental management accounting (EMA) concepts, and (3) environmental data captured by the GRI guidelines along with environmental management accounting (EMA) concepts and environmental information disclosed in sustainability reporting for stakeholder demand and investment decisions of Thai listed companies. Review of the literature is discussed next.

\section{Literature review}

\subsection{Management accountant's roles in sustainability reporting system}

Management accountant's roles drives as a collaborator with a company in capturing, identifying, and measuring environmental data based on environmental management accounting concepts/practices. This would assist a company to move toward corporate sustainability as a business goal (Neungruthai Petcharat, 2012). They also fulfil their traditional role in identifying and measuring all sources of expenditures paid for environmental improvement (Collins, Lawrence, Roper, \& Haar, 2011). In this relation, environmental accounting should be developed or designed as a business tool and mechanism such a conceptual model or framework to support their firms in achieving sustainability targets (Collins et al., 2011). However, management accountants could not hold with respect to sustainability accounting and collaboration of financial and non-financial information (Collins et al., 2011) in 
relation to the environmental aspects. Such information relating to a company's effective sustainability report to create shared value, management accountants realize the link between environmental concerns and sustainability accounting practices as providers (Collins et al., 2011). Management accountants' roles should be ideally placed to provide accurate environmental information while having knowledge of, and skills in sustainability accounting concepts/practices (ICAEW, 2004). This would help a company to fully capture accounting information on environmental factors to integrated in a company's internal reports and voluntary disclosures to fulfil the needs of stakeholders and public (ICAEW, 2004). Thus, management accountants should play an important role in creating greater relationship between a company and its stakeholders. Management accountants' roles in this study focus on creating environmental sustainability and explaining why a company needs to create more accurate accounting information on environmental factors. Environmental data captured based on the indicators of the Global Reporting Initiatives and environmental management accounting practices creates data accuracy to enable more effective decision-making and reporting purposes.

\subsection{Environmental sustainability accounting}

Sustainability accounting has been introduced to a sustainable company as a business tool to manage environmental and social costs, as well as providing cost information for business decision-making and disclosure (UNDSD, 2001). It aims at maintaining the balance between human activities and environmental patterns to sustain development in the long-term (Berkel, 2003). In order to meet the concerns of stakeholders, environmental accounting (EA) is considered appropriate to evaluate internal and external costs of the environment resulting from production and service processes (The Sigma Project, 2003; UNDSD, 2001). It also aims to analyse, evaluate and identify environmental costs in order to estimate costs for future production (UNDSD, 2001). Environmental accounting has two components: environmental management accounting (EMA) and environmental financial accounting (EFA) (IFAC, 2005). Environmental management accounting assists companies to create accurate accounting data on environmental factors for business decision-making and reporting purposes. Environmental management accounting (EMA) is designed as a business tool to not only manage costs of environmental protection but also provide environmental information to support financial reports for management decision in relation to environmental performance (Burritt \& Saka, 2006). Environment management accounting (EMA) provides a company with a way to identify and measure environmental indicators within and external organizations to support significant concerns of external stakeholders (governments, shareholders, etc.) (Burritt \& Saka, 2006). It aims to deal with cost identification and measurement of environmental transactions and other events that could have impacts on financial position and/or financial performance of firms (Moisescu \& Mihai, 2006).

\subsection{A corporate sustainability in Thai context}

In Thailand, a corporate responsibility agenda has been mainly driven by the concerns of developed countries to broaden the scope and content of mainstream CSR disclosures economic, environmental, and social performance (Taweephol, 2000). A corporate sustainability in Thai context is however not widely well-known (Neungruthai Petcharat \& Mula, 2013). Companies in Thailand appear lacking intention to report environmental performance along with eco-efficiency to add shareholder value in market place. Management accountant's roles in moving toward a corporate sustainability should be involved in setting sustainability strategies, thus supporting firm to achieve the best sustainability outcomes (Cullen \& Whelan, 2006). Foreign investors have noticed that Thai economic and manufacturers have resulted 
in the depletion of natural resources including forests and rivers which create serious pollution in surrounding areas (Trotman, 1981). Environmental issues of Thai companies have been significantly concerned by foreign investors, particularly those related to quality of life and working standards of employees and environmental pollution. In dealing with this issue, governmental agencies have provided a better framework for more effective business practices when reporting accounting information on environmental effects. The emergence of CSR and variations in its implementation has become increasingly important to sustainable development of firms. The linkage between CSR and good corporate governance has been recognized as an important role of stakeholders engagement initiatives (Watchaneeporn Setthasakko, 2010).

\section{Research design}

Thai companies disclose environmental performance to fulfil the needs of its stakeholders in order to add shared value in marketplace. Environmental information provided in annual reports and CSR disclosures of Thai companies are explored to seek where data accuracy. ABC approaches help capture environmental data from all sources of expenditures paid for environmental reduction and management (Cãpusneanu, 2008; Jasch, 2009). Environmental data captured by current management accounting practices are based on the indicators of the Global Reporting Initiatives (GRI, 2011). In this relation, environmental management accounting (EMA) practices could be employed for more accurate accounting data on environmental factors for business decision-making and reporting purposes (IFAC, 2005; Burritt \& Saka, 2006). Theoretical framework was drawn underlying review of the literature as shown below.

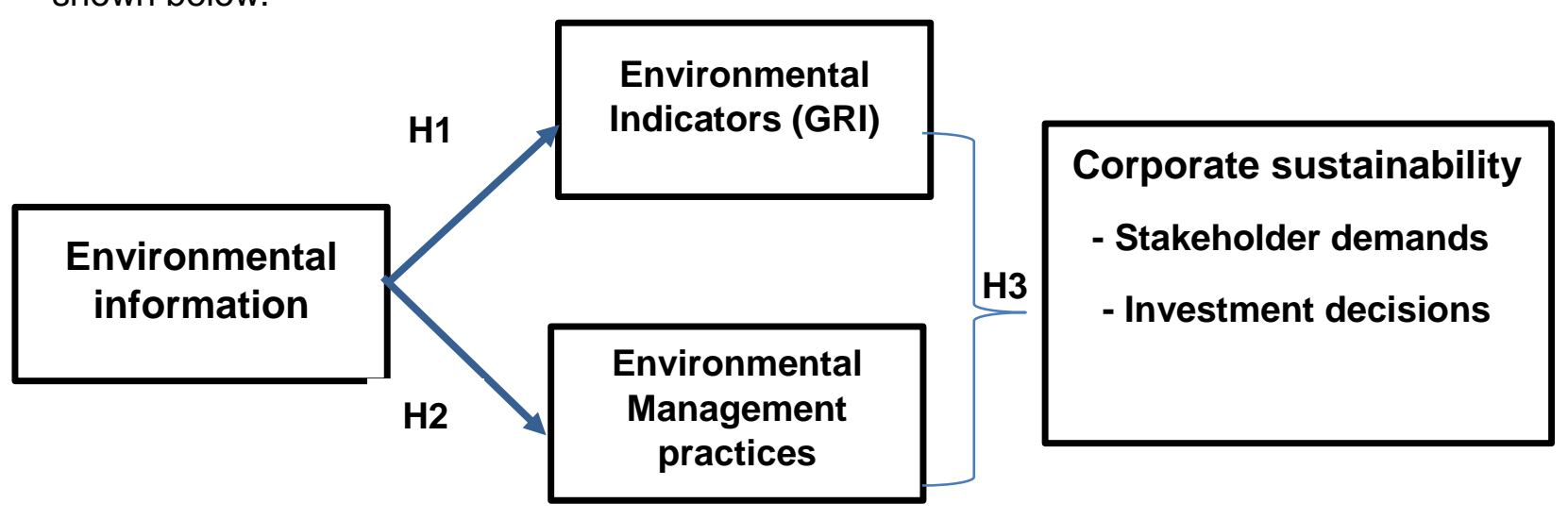

Figure 1: Management accountants' roles in sustainability reporting system

Hypothesises are posed to seek an association between environmental information in annual report and CSR disclosures of companies in Thailand and the environmental indicators of the Global Reporting Initiatives.

$\mathbf{H}_{1}$. Environmental data in a company's reports is positively related to the indicators of the Global Reporting Initiatives (GRI)

$\mathbf{H}_{2 .}$ Environmental indicators in a company's reports are positively related to the environmental management accounting (EMA) concepts

$\mathbf{H}_{3 .}$ Environmental data captured GRI guidelines and environmental management accounting (EMA) concepts are related to the corporate sustainability reporting system for stakeholder demand and investment decisions 


\section{Research methodology}

The study applied quantitative research approaches to collect and analyse data. A set of survey was created to conduct environmental data in annual reports and corporate social responsibility of two-hundred companies in Thailand. Purposive sampling methods were employed to select two-hundred companies those have incorporated environmental information in annual reports and corporate social responsibility (CSR) disclosures for quantitative study from industrial products, consumer products, construction, agriculture and food product, and technology were targeted. Regression analysis methods were applied to test hypothesises. A stepwise multiple regression analysis methods were conducted to evaluate the independent variables entered according to their statistical contribution in explaining the variance in the dependent variables.

\section{Findings}

The prediction consists of three predictors and was reach in three steps with no variables removed. The results show that $\mathrm{H} 1$ is statistically significant, $F(3,196)=14206.609, p<.001$ (Table 2), and accounted for the variance of environmental indicators of the GRI ( $R 2=.998$, Adjusted $R 2=.995$ ) (Table 1 ). It determines that the predictors of environmental indicators of the GRI are related to the environmental data in internal reports, annual reports, and CSR disclosures of a sampling group. Thus, $\mathbf{H}_{1}$, Environmental data in a company's reports is positively related to the indicators of the Global Reporting Initiatives is supported.

Table 1: The results of Model Summary - Environmental indicators of the GRI

Model Summary

\begin{tabular}{lrrrr}
\hline Model & $\mathrm{R}$ & $\mathrm{R}$ Square & Adjusted R Square & $\begin{array}{r}\text { Std. Error of the } \\
\text { Estimate }\end{array}$ \\
\hline 1 & $.995^{\mathrm{a}}$ & .990 & .990 & .12097 \\
2 & $.996^{\mathrm{b}}$ & .991 & .991 & .11230 \\
3 & $.998^{\mathrm{c}}$ & .995 & .995 & .08196 \\
\hline
\end{tabular}

a. Predictors: (Constant), Env. in CSR

b. Predictors: (Constant), Env. in CSR and annual reports

c. Predictors: (Constant), Env. in CSR, Env. in annual reports, Env. in internal report

Table 2: The results of ANOVA - Environmental indicators of the GRI 
ANOVA $^{\mathrm{d}}$

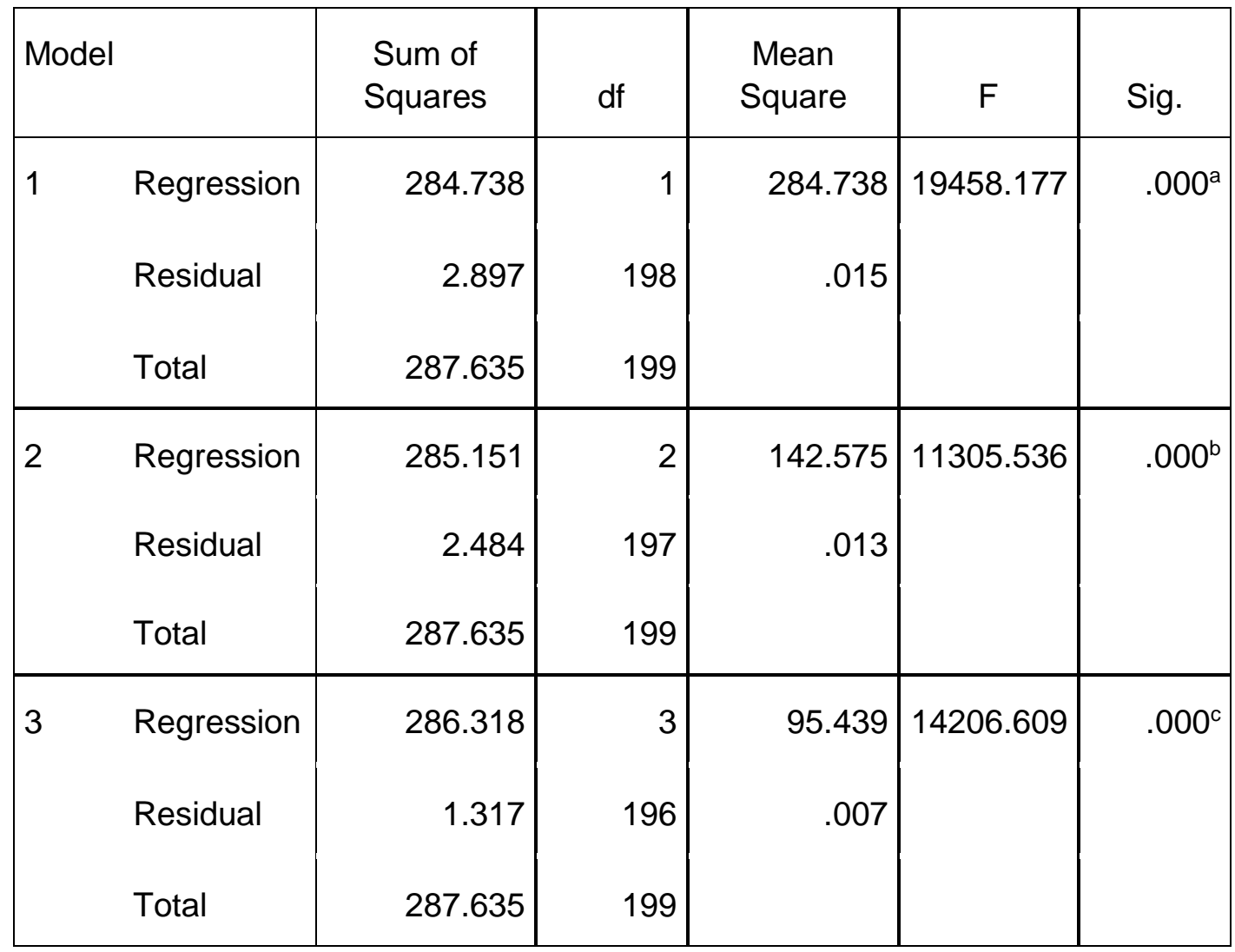

a. Predictors: (Constant), Env. in CSR

b. Predictors: (Constant), Env. in CSR and annual reports

c. Predictors: (Constant), Env. in CSR, Env. in annual reports, Env. in internal report

d. Dependent Variable: Env. indicators in the GRI

This study further analysed environmental indicators in a company's reports whether captured based on the concepts or practises of the environmental management accounting (EMA). The prediction consists of three predictors - environmental data in internal reports, annual reports, and CSR disclosure and was reach in three steps with no variables removed. The results show that $\mathrm{H}_{2}$ is statistically significant, $F(3,196)=4752.906, p<.001$ (Table 4), and accounted for the variance of environmental data identified by the EMA concepts/practices ( $R 2=.993$, Adjusted $R 2=.986$ ) (Table 3 ). It determines that the predictors of environmental data identified by the EMA practices are positively related with the environmental data in internal reports, annual reports, and CSR disclosures of a sampling group. Thus, H2, Environmental indicators in a company's reports are captured based on environmental management accounting concepts is supported. 
Table 3: The results of Model Summary - Environmental data identified by EMA practices

\begin{tabular}{lrrrr}
\multicolumn{5}{c}{ Model Summary } \\
\hline Model & $\mathrm{R}$ & R Square & $\begin{array}{c}\text { Adjusted R } \\
\text { Square }\end{array}$ & $\begin{array}{c}\text { Std. Error of } \\
\text { the Estimate }\end{array}$ \\
\hline 1 & $.991^{\mathrm{a}}$ & .982 & .981 & .16987 \\
2 & $.993^{\mathrm{b}}$ & .986 & .986 & .14897 \\
3 & $.993^{\mathrm{c}}$ & .986 & .986 & .14624 \\
\hline
\end{tabular}

a. Predictors: (Constant), Env._CSR

b. Predictors: (Constant), Env._CSR, Env._annual reports

c. Predictors: (Constant), Env._CSR, Env._annual report, Env._internal report

Table 4: The results of ANOVA - Environmental data identified by EMA practices 


\begin{tabular}{|c|c|c|c|c|c|c|}
\hline \multicolumn{7}{|c|}{ ANOVA $^{d}$} \\
\hline \multicolumn{2}{|c|}{ Model } & \multirow{2}{*}{$\begin{array}{r}\begin{array}{c}\text { Sum of } \\
\text { Squares }\end{array} \\
303.429\end{array}$} & \multirow{2}{*}{$\begin{array}{ll}\text { df } & \\
& \\
& 1\end{array}$} & \multirow{2}{*}{$\begin{array}{l}\begin{array}{l}\text { Mean } \\
\text { Square }\end{array} \\
303.429\end{array}$} & \multirow{2}{*}{$\begin{array}{c}\mathrm{F} \\
10515.093\end{array}$} & \multirow{2}{*}{$\begin{array}{l}\text { Sig. } \\
.000^{\mathrm{a}}\end{array}$} \\
\hline 1 & Regression & & & & & \\
\hline & Residual & 5.714 & 198 & .029 & & \\
\hline & Total & 309.143 & 199 & & & \\
\hline \multirow[t]{3}{*}{2} & Regression & 304.771 & 2 & 152.386 & 6866.357 & $.000^{\mathrm{b}}$ \\
\hline & Residual & 4.372 & 197 & .022 & & \\
\hline & Total & 309.143 & 199 & & & \\
\hline \multirow[t]{3}{*}{3} & Regression & 304.951 & 3 & 101.650 & 4752.906 & $.000^{\circ}$ \\
\hline & Residual & 4.192 & 196 & .021 & & \\
\hline & Total & 309.143 & 199 & & & \\
\hline
\end{tabular}

a. Predictors: (Constant), Env_CSR

b. Predictors: (Constant), Env_CSR, Env_annual report

c. Predictors: (Constant), Env_CSR, Env_annual report, Env_internal report

d. Dependent Variable: Env_EMA practice

In addition, management accountants' roles in acting as collaborators with a company to identify and measure environmental information from all sources of expenditures paid for improvement in environment were examined. The prediction consists of two predictors environmental data in the CSR disclosure and sustainable value creation and was reach in three steps with no variables removed. The results show that $\mathrm{H}_{3}$ is statistically significant, $F(2$, $197)=6358.962, p<.001$ (Table 6 ), and accounted for the variance of environmental data identified by the EMA concepts/practices ( $R 2=.992$, Adjusted $R 2=.985)$ (Table 5). Thus, H3, Environmental data captured GRI guidelines and environmental management accounting (EMA) concepts are related to the corporate sustainability reporting system for stakeholder demand and investment decisions is also supported.

Table 5: The results of Model Summary - Management accountants' roles for sustainable value 
Model Summary

\begin{tabular}{|c|c|c|c|c|}
\hline Model & $\mathrm{R}$ & R Square & $\begin{array}{l}\text { Adjusted R } \\
\text { Square }\end{array}$ & $\begin{array}{l}\text { Std. Error of } \\
\text { the Estimate }\end{array}$ \\
\hline 1 & $.991^{a}$ & .982 & .982 & .16571 \\
\hline 2 & $.992^{\mathrm{b}}$ & .985 & .985 & .15472 \\
\hline
\end{tabular}

a. Predictors: (Constant), Env_Sustainable value

b. Predictors: (Constant), Env_Sustainable value, Env_CSR

Table 6: The results of ANOVA - Management accountants' roles for sustainable value

ANOVA $^{c}$

\begin{tabular}{|c|c|c|c|c|c|c|}
\hline \multicolumn{2}{|c|}{ Model } & Sum of & $d f$ & Mean & $\mathrm{F}$ & Siq. \\
\hline 1 & Regression & 303.706 & 1 & 303.706 & 11060.295 & $.000^{\mathrm{a}}$ \\
\hline & Residual & 5.437 & 198 & .027 & & \\
\hline & Total & 309.143 & 199 & & & \\
\hline 2 & Regression & 304.428 & 2 & 152.214 & 6358.962 & $.000^{\mathrm{b}}$ \\
\hline & Residual & 4.716 & 197 & .024 & & \\
\hline & Total & 309.143 & 199 & & & \\
\hline
\end{tabular}

a. Predictors: (Constant), Env_Sustainable value

b. Predictors: (Constant), Env_Sustainable value, Env_CSR

c. Dependent Variable: Env_Managemenat accountant's roles 


\section{Conclusion}

This study concludes that environmental performance indicators in annual reports and CSR disclosures of a sampling group are relevant to the indicators of the Global Reporting Initiative (GRI) that most widely used standardized sustainability reporting framework. Management accountants identify and measure environmental data based on the environmental management accounting concepts. Environmental data of a sampling group enables more effective decision-making at boardroom level and support stakeholders' concerns. This would help sustainable companies to establish ecosystem and provide transparency into environmental aspects to maintain their own sustainability transformation. Management accountants' roles in encouraging a company to accurately incorporate environmental and data in its reports drive as collaborators with a company to employ sustainability accounting concepts/practices for cost identification and measurement. This provides sustainable companies with a way to report their environmental performance in both mandatory and a variety of voluntary disclosures. Environmental data in annual reports and CSR disclosures fulfils sustainability management accounting practices for cost identification and measurement, thus creating data accuracy when decision-making needs to be made. As a result, sustainable companies become better competitors in terms of intelligent operational efficiency, competitive differentiation, and sustainable growth, thus building a profitable, longterm, values-driven business to the environment, society, and community in which it operates.

\section{Reference}

Bennett and James. (1998), The Green Bottom Line: current practice and future trends in environmental management accounting, Greenleaf Publishing, Sheffield.

Berkel, R. V. (2003), "Managing for Sustainable Development: Using environmental management accounting and sustainable development reporting", CPA congress, Vol. 21 No. 23, pp. 1-18.

Burritt, R. L. and Saka, C. (2006), "Environmental management accounting applications and ecoefficiency: case studies from Japan", Cleaner Production, Vol. 14 No. 0, pp. 1262-1275. https://doi.org/10.1016/j.jclepro.2005.08.012

Cãpusneanu, S. (2008), "Implementation Opportunities of Green Accounting for Activity-Based Costing (ABC) in Romania", Theoretical and Applied Economics, Vol. 1 (518) No. 1(518), pp. 57-62.

Collins, E., Lawrence, S., Roper, J. and Haar, P. J. (2011), "Sustainability and the role of the management accountant", in Research executive summary series Chartered Institute of Management Accountants, London.

Cullen, D. and Whelan, C. (2006), "Environmental Management Accounting: The State Of Play ", Journal of Business \& Economics Research Vol. 4 No. 10, pp. 1-4.

GRI. (2011), "Indicator Protocols Set Environment (EN) Mining and Metals Sector Supplement", available

at:

http://www.globalreporting.org/ReportingFramework/ReportingFrameworkDownloads/ (accessed 12 July 2010).

ICAEW. (2004), "Sustainability: The Role of Accountants \& Sustainable Business Initiative ", in. Institute of Chartered Accountants in England \& Wales, London.

IFAC. (2005), "Environmental Management Accounting", in. International Federation of Accountants, New York, pp. 19, 22- 23, 26-27 
Jasch, C. (2009), Environmental and Material Flow Cost Accounting: Principles and Procedures Springer Vienna, Austria.

Moisescu, F. and Mihai, O. (2006), "Environmental Financial Accounting", Economics and Applied Informatics No. 1, pp. 79-84.

Muttanachai Suttipun and Patricia Stanton. (2012), "A study of Environmental Disclosures by Thai listed Companies on Websites", Procedia Economics and Finance, Vol. 2 No. 0, pp. 9-15. https://doi.org/10.1016/S2212-5671(12)00059-7

Neungruthai Petcharat. (2012), "Moving toward a More Sustainable: CSR Development in Thailand", Global Review of Accounting and Finance, Vol. 5 No. 2, pp. 16-35. https://doi.org/10.21102/graf.2014.09.52.02

Neungruthai Petcharat and Mula, J. (2013), "Toward a Conceptual Model for Sustainability Financial Reporting System", in Accounting and Finance Association of Australia and New Zealand (AFAANZ) Conference, Perth Australia (7-9 July, 2013)

Nickie Petcharat and Mula, J. M. (2012), "Toward a Conceptual Design for Environmental and social Cost Identification and Measurement", Journal of Financial Reporting and Accounting Vol. 10 No. 1, pp. 34-54. https://doi.org/10.1108/19852511211237435

Nongnooch Kuasirikun and Sherer, M. (2004), "Corporate social accounting disclosure in Thailand", Accounting, Auditing \& Accountability Journal, Vol. 17 No. 4, pp. 629-660. https://doi.org/10.1108/09513570410554588

Panisara Kongpunya, Phapruke Ussahawanitchakit and Chularat Khankaew. (2011), "Building accounting sustainability of listed firms in Thailand: how does it affect accounting disclosure and disclosure quality? ", in Journal of Academy of Business and Economics International Academy of Business and Economics, Bangkok, Thailand.

Pareena Prayukvong and Olsen, M. (2014), "Research on the CSR Development in Thailand", in. The Network of NGO and Business Partnership for Sustainable Development (Thailand): UN Volunteers.

Rowbottom, N. and Lymer, A. (2009), "Exploring the use of online corporate sustainability information", Accounting Forum, Vol. 33 No. 2, pp. 176-186. https://doi.org/10.1016/j.accfor.2009.01.003

Somporn Thapanachai. (2000), "Textile and garment firms urged to improve standards: Western customers ask more questions about worker rights", Bangkok Post. pp. 3.

Taweephol, U. (2000), "Environmental Accounting : A case study of the development of a model for the preparation and disclosure of information about the environment in the financial reports of companies listed on the Stock Exchange of Thailand.", University of Chamber of Commerce., Bangkok, Thailand.

Thapat Silalertruksa and Gheewala, S. H. (2012), "Environmental sustainability assessment of palm biodiesel production in Thailand", Energy, Vol. 43 No. 1, pp. 306-314. https://doi.org/10.1016/j.energy.2012.04.025

The Sigma Project. (2003), "The Sigma Guidelines - Toolkit: Sustainability Accounting Guide", in. The UK Department of Trade and Industry (DTI), London.

Trotman, K. T. (1981), "Associations between social responsibility disclosure and characteristics of companies", Accounting, Organizations and Society, Vol. 6 No. 4, pp. 355-362. https://doi.org/10.1016/0361-3682(81)90014-3 
Tungrhapheephakorn, S. (2001), "Management in Thai factories and university research projects on dangerous material", in Phujudkarnraiwan, Bangkok, pp. 3.

UN. (2008), Achieving Sustainable Development and Promoting Development Cooperation: Dialogues at the Economic and Social Council, United Nations, Economic \& Social Affairs New York.

UNDSD. (2001), "Environmental Management Accounting Procedures and Principles", in. United Nations Division for Sustainable Development (UNDSD), New York, pp. 8.

Watchaneeporn Setthasakko. (2010), "Barriers to the development of environmental management accounting An exploratory study of pulp and paper companies in Thailand", EuroMed Journal of Business, Vol. 5 No. 3, pp. 315-331. https://doi.org/10.1108/14502191011080836 